\title{
THEORETICAL AND LEGAL PERSPECTIVE ON CERTAIN TYPES OF LEGAL LIABILITY IN CRYPTOCURRENCY RELATIONS
}

\author{
Oleksii Drozd' \\ National Academy of Internal Affairs, Ukraine \\ Yaroslav Lazur ${ }^{2}$ \\ Uzhhorod National University, Ukraine \\ Ruslan Serbin ${ }^{3}$ \\ National Academy of Internal Affairs, Ukraine
}

\begin{abstract}
The aim of this article is to study the theoretical, methodological, and legal possibilities of application of certain types of legal responsibility to the relations, which are connected with cryptocurrency (bitcoin). Some types of liability in the field of cryptocurrency relations make the subject of the study. Methodology. The research is based on a comparison of legal regulation of the sphere of cryptocurrency in Ukraine and in foreign countries. Advantages and disadvantages of different modes of cryptocurrency turnover are determined: from direct prohibition to granting the status of the official payment system. It is made on the basis of the analysis of peculiarities of the circulation of virtual money in Australia, Germany, the Netherlands, New Zealand, Singapore, Indonesia, China, the Russian Federation, Bolivia, Ecuador, Thailand, Vietnam, the USA, Japan, Spain, and some other countries. On the basis of the comparative legal study of certain provisions of the civil, administrative, tort, and criminal legislation of Ukraine, the possibilities and limits of the application of certain types of legal responsibility to violations in the field of cryptocurrency are determined. The results of the comparative legal study have shown that, unlike most foreign countries, in Ukraine, there is no legislative consolidation of the legal status of the virtual currency. In this regard, today in the national legislation, there are no direct rules that would predict the occurrence of administrative, criminal or civil liability for the offenses in the field of cryptocurrency relations. Practical impact. Since guarantees of compulsory restoration or protection of violated law play an important role in the legal regulation of any social relations, the proper legislative regulation of public relations in the sphere of crypto currency circulation is an urgent problem today, including with the help of establishing liability for the offenses in this field. Correlation/Authenticity. Comparative and legal research of legal regulation of the sphere of crypto currency gives us a better understanding of the most promising directions of development of administrative, criminal, and civil liability in this field.
\end{abstract}

Key words: cryptocurrency, legal liability, transaction, licensing, Bitcoins, crypto exchange, crypto market.

JEL Classification: D23, D45

\section{Problem statement}

Nowadays, the majority of crypto-asset operations are outside the legal field, which is good to some extent, because no one interferes with them. On the other hand, there are risks, of course. In particular, state financial monitoring and control is impossible. This is really undesirable because not all operations related to crypto- assets activities are positive. There is a danger of using cryptocurrencies in transactions that are beyond the law. And it is necessary to create protection against such actions. Participants of the crypto market wait from the state not regulation, which is perceived by the IT sector as an unwanted interference but defying legal status. Under such conditions, legal aspects of certain types of

\footnotetext{
Corresponding author:

${ }^{1}$ Department of Research Work Organization, National Academy of Internal Affairs.

E-mail: alex0674682444@gmail.com

https://orcid.org/0000-0002-4514-6594

${ }^{2}$ Faculty of Law, Uzhhorod National University/

E-mail: lazurs1980@gmail.com

${ }^{3}$ National Academy of Internal Affairs/

E-mail: r.s.1978@ukr.net
} 
legal liability for violations in the field of cryptocurrency become of particular relevance.

\section{Analysis of recent research and publications}

The study of the phenomenon of cryptocurrency (Bitcoin) is revealed in the works of such scholars as: Aiganym E. Seitim (Aiganym E. Seitim. (2016), O. S. Badzym (Badzym, Drevush), Yu. V. Hava (Hava), B. V. Derevianko (Derevianko, 2017), A. R. Drevush (Badzym, Drevush), I. M. Doronin (Doronin), L. L. Neskorodzhena (Neskorodzhena, 2017), O. Poplavskyi (Poplavskyi, 2016), N. Pantielieieva (Pantielieieva, 2015). Evidently, most of the researches on this problem relate to scientific works of specialists in economics, although the attention of lawyers has recently been attracted.

The authors consider theoretical and legal possibilities of applying certain types of legal liability, in particular, civil, administrative, and criminal liability to relations involving cryptocurrency (Bitcoin). Besides, specific features of such a phenomenon as cryptocurrency (Bitcoin) from the perspective of jurisprudence are identified to draw the attention of, first of all, scientists and scholars to possible further scientific research as for the introduction of this phenomenon in modern Ukrainian legislation.

\section{The main material}

It is important that cryptocurrency, in terms of national legislation, is not money. In November 2014, the National Bank explained that it considered "virtual currency" Bitcoin as money surrogate, which was not provided with real value and cannot be used by individuals and legal entities on the territory of Ukraine as a means of payment, as this was contrary to the norms of Ukrainian legislation.

However, the clarification of the NBU does not provide for responsibility for the use of cryptocurrency and, therefore, it is sooner a certain warning than the norm. Considering disputes over virtual transactions, courts have agreed that cryptocurrency is neither a thing nor property rights and does not possess any material features at all.

Throughout the world, the relation to the system of virtual money is significantly different. Some countries encourage them in every way (Australia, Germany, the Netherlands, New Zealand, Singapore), some of them set serious limits for digital money (Indonesia, China, Russia). At present, direct bans are installed only in Bolivia, Ecuador, Thailand, and Vietnam. Most governments have opted for neutrality avoiding any decisions regarding the virtual currency.

In some countries, for example in Japan, cryptocurrency is recognized as a financial asset. Meanwhile, electronic money is not considered to be legal tender, but a means of exchange. In Canada, on the contrary, you can even get a digital salary. Obtained by mining, cryptocurrency is subject to income tax.

In 2014, Spain recognized Bitcoin as an official payment system. This initiative came from the tax inspectorate of the country, which analysed the use of cryptocurrency in the country and concluded that this process should be legalized and taxed.

Such statistics lead to the conclusion that the recognition of digital currency depends largely on the level of state development. States with a weak economy are not ready to introduce such payment systems. On the contrary, highly developed countries still strive to regulate electronic payments by controlling and taxing them (Misnik, 2017).

At the same time, some scholars attribute to the main advantages of cryptocurrency:

1) low cost of transfers, which is especially relevant for micro-transmissions and micro-insurance;

2) relative rate of money flow between different users and countries;

3) simplicity and flexibility for the user with a simultaneous security system;

4) public registration of transactions and pseudonymity of accounts ensure both transparency of the system and its secrecy;

5) impossibility to confiscate funds;

6) independence of capital movement from banking system operation;

7) fewer bureaucratic obstacles (Poplavskyi, 2016).

For example, a scientist, B. V. Derevianko, in his studies of cryptocurrency relations distinguishes risks of transactions with cryptocurrency (Bitcoins) of citizens and business entities of Ukraine.

The scientist identifies:

- technological risks (consist of possible voluntary or enforced refusal of human civilization from modern computers and/or Internet technologies);

- legal risks (one-way refusal and change of services for the placement of a wallet, violation of contract terms, etc.);

- economic and legal risks (possibility of falling demand for cryptocurrency due to increased demand for real goods, the economic crisis, world war or because of state prohibition and the emergence of a new cryptocurrency) (Derevianko, 2017).

In our opinion, the most widespread offenses in cryptocurrency relations are:

- blocking addresses of electronic wallets and electronic exchanges dealing with Bitcoins or another cryptocurrency;

- impossibility to withdraw honestly earned Bitcoins from an e-wallet;

- withdrawal of money from the account on the site and their absence in the e-wallet (violation of transactions); - the absence of agreement of the user with the proposed terms of an affiliation contract in creating an e-wallet or registration on the electronic exchange; 
- thefts of cryptocurrency due to a cyberattack on a crypto-exchange, etc.

It is important to consider theoretical and legal possibilities of applying certain types of legal liability, in particular civil, administrative, and criminal liability to relations involving cryptocurrency (Bitcoin).

In the legal regulation of any social relations, guarantees of enforced restoration or protection of the violated law, in particular, the institute of civil liability, play a significant role.

Issues of civil liability include defining the amount of liability, and grounds for bringing to civil liability, as well as release, considering the fault of the victim (debtor), etc. (Kuznetsova, 2013). In civil law, the imposition of property sanctions on offenders is an inevitable consequence of a civil offense commission and the result of failure or improper performance of civil rights and obligations assumed.

The collection of property sanctions for the commission of an offense is considered one of the most effective means for the proper fulfilment of their subjective rights and obligations by participants of civil legal relations, so that civil liability guarantees protection of subjective rights and obligations of parties to civil legal relations, as well as stability of property turnover (Bodnar, 2014; Bodnar, 2007; Odnostoronnia vidmova u dohovirnykh zoboviazanniakh).

According to Kuznetsova, violation of rights of parties to civil legal relations necessitates the restoration of the violated law, comprising civil liability applying. Accordingly, the basis for such a liability is the very violation of subjective civil law (Borisova, 2004). Moreover, Shevchenko emphasizes that it is a civil law that is characterized by the restoration of subjective civil rights of persons protected by law and carried out on various principles and with the help of civil liability (Shevchenko, 2012).

According to Maidanyk, features of civil liability are: a) compensatory nature; b) state condemnation and coercion; c) property nature; direct responsibility of the offender to the victim; sanctions; the possibility of voluntary compensation for damage by the offender without judicial or other state bodies' intervention (Maidanyk, 2013).

Civilised literature reveals that for the onset of contractual liability, at least two reasons are required: existence of a contractual obligation, formally valid and such that does not violate the law in principle, as well as violation of this obligation, that is its non-execution or its inappropriate execution due to quantity, quality, the term (Biriukov, Zaika, 2014; Zaika, Timush, Loviak, 2014).

It is difficult to disagree with the thesis but to define the contract as one of the grounds of responsibility is not entirely correct. In this context, non-contractual liability is meant. Thus, Lovik notes that non-contractual obligations arising as a result of a violation of property and personal non-property rights of the subject are intended to ensure the most complete restoration of violated rights at the expense of the perpetrator of damage or at the expense of other persons subject to such a refund by law (Loviak, 2014).

Features of civil liability are: it is always the responsibility of one person to another; it is always property liability; the overall size of responsibility must coincide with the size of injury or damage caused (Pushkin, Samoilenko, Shishka et al. 1996).

Therefore, civil liability is characterized by the imposition on offenders certain measures that are property sanctions. Thus, civil liability can be defined as a measure of legal influence, which is imposed on a person for an offense committed by him/her (Gribanov, 1973).

Thus, in the perspective of the issue under consideration, the possibility of civil liability should be noted. Mostly, it will concern cases of compensation for damage arising from contravention of the contractual basis for services to create and maintain e-wallets, cryptoexchanges activity. Thus, for example, an agreement on the use of the service PingBlockchain.com, where section 7 "Warranties and responsibilities of the parties" states:

7.1. The Service provides its services on "as is" basis as they are described on pages of the Service site and does not offer any additional warranties.

7.2. The Service guarantees fulfilment of obligations to the User only within the limits transferred by the User to the Service for the transaction.

7.3. The service will do its utmost but does not guarantee that its services will be available 24 hours a day. The Service shall not be liable for damages, loss of profit, and other expenses of the User arising in connection with the impossibility of access to the site and services of the Service (Uhoda pro vykorystannia servisu).

Therefore, the content of this electronic document neither reflect nor establish the terms of transaction validity, provided for in the Civil Code of Ukraine (hereinafter - the CC of Ukraine). Thus, Article 203 of the CC of Ukraine clearly states:

- the content of transaction cannot contradict the CC of Ukraine, other acts of civil law, as well as the interests of the state and society, its moral principles;

- performing the transaction person must possess necessary civil legal capacity;

- the expression of the will of transaction participant must be free and consistent with his internal will;

- the transaction should be carried out as provided for by law;

- the transaction should be aimed at relevant legal consequences, which are caused by them (Tsyvilnyi kodeks Ukrainy).

The institution of moral harm should not be excluded. For example, for months, a person has been saving 
money on an e-wallet, and one day all disappears somewhere. Does it make the person suffer morally or mentally? The human factor says "yes", but from a legal point of view, this fact needs proof.

In the relations under consideration, the complexity of civil liability implementation will be in the following. First, claims must be proved in the court, and second, evidence. How should the relevant evidence base for a court inquiry be collected, if everything is presented only electronically? Although civil law contains positions on an electronic signature (Loviak, 2014), the electronic form of transaction, but cryptocurrency relations have their features, which, unfortunately, are not yet adequately reflected in civil law.

On November 10, 2014, the official website of the National Bank provided information that cryptocurrencies, in particular, Bitcoin, were a monetary surrogate, to be precise, document $[\mathrm{s}]$ in the form of banknotes that were different from the monetary unit of Ukraine, issued not by the National Bank of Ukraine and made in order to make payments in economic turnover, in addition to currency values. This is the definition of Article 1 of the Law of Ukraine "On the National Bank of Ukraine" of May 19, 1999, No. 679-XIV. In accordance with the second part of Article 32 of the Law, on the territory of Ukraine, the use of money surrogates as a means of payment is prohibited. Therefore, in contractual relations cryptocurrency as the price of the contract (and this is an essential condition) cannot be applied. Although, according to the literal interpretation of Article 32, the issue and circulation of cryptocurrency as a money surrogate, in contrast to the issue and circulation of monetary units, are not prohibited in Ukraine until such cryptocurrency is offered/accepted by the customers for settlements.

Under civil law relations, the possibility of legal inheritance of cryptocurrency or its use in credit relations or in relation to collateral cannot be confirmed confidently. Although the civil law does not prohibit including cryptocurrency into a will or lay as property rights, and even pay with cryptocurrency for contractual obligations or services. We support the opinion of some scholars that while the state has not decided on the status of cryptocurrency, they must be treated as goods. Currently, in Ukraine, large deals with cryptocurrencies are being conducted using the Barter Agreement, for example, the well-known agreement on "selling" an apartment for Bitcoin was, in fact, an "exchange". The Barter Agreement stipulates that each party undertakes to transfer goods to another party in exchange for other goods (Rudenko, Sadovnichy).

The next type of legal responsibility is administrative. Let us draws attention to provisions of the Article 155-1 "Violation of the procedure for payments" of the Code of Ukraine on Administrative Offenses (hereinafter the CAO).
Thus, violation of the established by law procedure for conducting payments in trade, public catering and services leads to a fine imposed on persons, who carry out payment transactions, from two to five tax-free minimum incomes of citizens and on officials from five to ten non-taxable minimum incomes of citizens (Kodeks Ukrainy pro administratyvni pravoporushennia).

Individuals such as business entities or legal entities (their subsidiaries, affiliates other separate units), which carry out transactions in payments in cash and (or) in non-cash form (using payment cards, payment checks, tokens, etc.) when selling goods (services rendered) in trade, catering and services, as well as authorized banks and business entities that execute foreign currency purchase and sale transactions, should be applied registrars of payment transactions. Registrar of payment operations is a device or software and hardware with implemented fiscal functions and which is designed to record payment transactions when selling goods (services), operations on purchase and sale of foreign currency and (or) registration number of sold goods (services). Registrars of payment transactions include electronic cash registers, electronic cash register recorder, computer-cash systems, electronic taximeter, vending machine, etc. (Kodeks Ukrainy pro administratyvni pravoporushennia. Naukovopraktychnyi komentar).

The leading legal point of this norm is consideration of services. After all, relations in cryptocurrency are service. For example, so-called programs, applications (Bitcoin faucets) provide an opportunity to accumulate free "Satoshi" for further profits. The abovementioned norm concerns business entities. Information resources for providing services in cryptocurrency are not business entities, although they provide services as for goods in the form of virtual money.

Sequentially, according to Article 2 of the Law of Ukraine "On Application of Registrars of Payment Transactions in Trade, Catering and Services", the payment transaction is the receipt of cash, payment cards, payment checks, tokens, etc. from the purchaser at the place of sale of goods (services), the repayment of cash for goods returned by the consumer (service not provided), and in the case of using a bank payment card, execution of corresponding payment transaction document for payment in cashless form for goods (services) by the bank of the purchaser or, in case of return of goods (refusal of service), registration of payment transaction documents for the transfer of funds to purchaser's bank (Pro zastosuvannia reiestratoriv rozrakhunkovykh operatsii u sferi torhivli, hromadskoho kharchuvannia ta posluh).

The norms provided for by Article 164-2 "Violation of financial legislation" and Article 166-5 "Violation of Banking Legislation, Legislation Regulating the Transfer of Funds in Ukraine, Regulatory Legal Acts of the National Bank of Ukraine or Conducting Risky 
Operations that Threaten Interests of Depositors or Other Lenders of Bank" of the CAO are both theoretical and applied.

For example, Article 164-2 of the CAO provides for the norm that the Concealment in the accounting of currency and other income, unproductive costs and losses, absence of accounting or keeping it with violation of the established procedure, inserting false data to the financial statements, failure to provide financial statements, late or poorly conducted inventory of cash and property, late submission for the consideration or approval of the annual financial plan of the enterprise of the state economy sector and the report on its implementation, obstruction of carrying out audits and inspections by officials of the state financial control body, failure to take measures of compensation for losses from shortages, embezzlement, theft and mismanagement by perpetrators entail imposition of a fine of eight up to fifteen nontaxable minimum incomes of citizens (Kodeks Ukrainy pro administratyvni pravoporushennia).

Therefore, the cryptocurrency market may facilitate income concealment, as bidding on crypto-exchange can be anonymous.

Consequently, the norm of Article 166-5 of the CAO uses the notion of "performing risky operations". Risk management is a process, by which a bank identifies risks, evaluates their scope, monitors, and controls risk positions, as well as considers the relations between different risk categories. The set of actions on risk management aims at ensuring achievement of such objectives as: risks must be clear and reasonable for the bank and its administration; risks must be within tolerance levels established by the supervisory board; risk-taking decisions must be consistent with the strategic objectives of the bank; risk-taking decisions must be specific and precise; expected profit should offset the risk taken; distribution of capital should correspond to the scope of the risks that the bank is exposed to; incentives to achieve high performance should be consistent with the level of tolerance to risk (Kodeks Ukrainy pro administratyvni pravoporushennia. Naukovo-praktychnyi komentar).

Unfortunately, risks apply only to banking institutions and the National Bank, in particular. Thus, it is appropriate to note that certain rules of administrative legislation contain conditional provisions for the regulation of cryptocurrencies in Ukraine. Some rules of the CAO operate with such terms as "service", "risk", "non-cash form of payment", which are inherent in activities in cryptocurrency relations. It is decisive that these terms apply to accredited business entities, while they are not applicable to e-services for the provision of services in the crypto market.

Positions of administrative liability are complicated by the lack of licenses to engage in such activities.

Administrative liability application is complicated by the lack of such activity licenses. The regulator of such activity could be the National Bank of Ukraine or another specially authorized body. Under such conditions, it would be possible to apply administrative measures to business entities providing financial services in the market of cryptocurrencies without a license or providing financial services in the market of cryptocurrencies in Ukraine.

Inspection of legislative provisions of the $\mathrm{CC}$ of Ukraine indicates that it does not contain a direct norm that would strengthen the possibility of criminal liability for violations in cryptocurrencies. Noticeably, Article 200 "Illegal Actions with Transfer Documents, Payment Cards and Other Means of Access to Bank Accounts, Equipment for Their Production" of the CC of Ukraine considers payment documents.

The term "other means of access to bank accounts..." is used in criminal law. Other means of access to bank accounts should be considered as any other, but documents for transfer and payment cards, documents or items, using which, with the knowledge and consent of bank employees, a person can access a particular bank account and carry out operations with funds that are located on such account. In particular, this other means is a bank identification card (ID card), which is an identifier in the form of a plastic or other type of card containing details specified by the bank, which identify the client and his accounts in the bank (Kryminalnyi kodeks Ukrainy: Naukovo-praktychnyi komentar).

For the issue under consideration, provisions of Article 190 "Fraud" and Article 222 "Fraud with Financial Resources" of the CC of Ukraine can be relevant. The subject of fraud is characterized by the possibility to be both a stranger's property and the right to such property. The right to property can be provided for by various documents, such as securities, a power of attorney to dispose of property, debt obligations, wills, etc. The objective side of fraud is seizure of property or acquisition of property rights by deception or abuse of trust. Due to fraudulent acts, the victim (an owner, a possessor, a person, who is in charge of property or under whose protection property is located) voluntarily transfers property or the right to property to an offender. The direct involvement of the victim in the transfer of property and the voluntary nature of his/her actions are mandatory indications of fraud that distinguishes it from the theft of property and other crimes against property (Kryminalnyi kodeks Ukrainy: Naukovopraktychnyi komentar).

Cryptocurrency fraud is a serious problem for such a developed country as the United States, whose bank regulators have drawn attention to the increase of these crimes. Having discovered that unregulated virtual currency sphere is very popular among online fraudsters, the New York State Department of Financial Services concluded that this kind of fraud was threatening US national security (Shapochka, 2014). 
The provision of Article 225 "Cheating of Purchasers and Customers" of the CC of Ukraine is worthy of attention, as it covers the concept of "another deception". "Another deception" is the use of any of the abovementioned methods, by means of which an offender receives from the purchaser or the customer a higher monetary amount that should have been paid for the goods or service in accordance with the established prices or tariffs. Another deception is, in particular, the sale of goods at a price that is higher than established (this way is also called "exceeding established retail prices"), selling of spoiled goods, lower grade goods at a higher price, exceeding the established prices and tariffs for household and communal services provided to the people, etc. The obligatory feature of this crime is the deceptive nature of related actions i.e. they are committed to making an impression of the rightness of offender's actions on the purchaser or the customer (Kryminalnyi kodeks Ukrainy: Naukovo-praktychnyi komentar).

In relations with cryptocurrency (Bitcoin), for example, the rate of the electronic money of e-wallet for cryptocurrency transaction to a bank card is often absent or do not correspond to provisions stated by the electronic resource.

From the perspective of national security, provisions of Article 209 "Legalization (Laundering) of Proceeds of Crime" and Article 209-1 "Intentional Violation of Requirements of the Legislation on Prevention and Counteraction to Legalization (Laundering) of Proceeds of Crime or Terrorist Financing" of the CC of Ukraine are of particular interest. The main direct object of the crime is established, in order to counteract involvement of "dirty" funds in economics, the order of economic activity, as well as the procedure for civil legal transactions in respect of personal and another similar usage of property not related to economic activity. An additional object is the interests of justice, normal functioning of the financial system, principles of fair competition.

In this case, currency may be in cash or in non-cash form (on a bank account and their turnover is governed by the law of obligations), be both national and foreign currency.

The Letter of the NBU dated December 8, 2014, No. 29-208/72889 states that transaction of Bitcoin for US dollars or other foreign currency has signs of the so-called financial pyramids functioning and may indicate a potential involvement in the implementation of dubious transactions in accordance with the law on counteraction to legalization (laundering) of proceeds of crime and terrorist financing. Countering the crimes of Article 209 and Article 209-1 of the CC of Ukraine is the practice of licensing, which is very common in the United States, Japan. Considering the issue, the European Union is going to adopt the relevant amendments to Directive (EU) 2015/849 "On Prevention of the Use of Financial System for the Purposes of Money Laundering or Terrorist Financing" (Plyta).
In such positions, we can conclude that the implementation of criminal liability in the field of cryptexchange relations also depends on licensing activities in Ukraine. The existence of a license minimizes violations in this area will allow every consumer of services in the field of cryptography to have open information about the issuer, the order of issue and operations on cryptocurrency (bitcoin or its various analogues). Therefore, implementation of criminal liability in cryptocurrency relations also depends on licensing activities in Ukraine. The presence of a license minimizes violations in this sphere, will allow every consumer of services in cryptocurrency to have open information about the issuer, the order of issue and operations on cryptocurrency (Bitcoin or its analogues).

\section{Conclusions}

An overview of certain provisions of Ukrainian legislation on the possibility of applying certain types of legal liability to violations in cryptocurrency enabled to conclude:

1. In the Civil Code of Ukraine, the CAO and the CC of Ukraine, currently no direct norms clearly establish the list of unlawful actions or offenses, for which it would be possible to bring offenders to one or another form of legal liability.

2. In relations under consideration, the complexity of civil liability implementation is in the following aspects: - the possibility of its occurrence in contractual and noncontractual obligations without civil-law regulation of specific violations of the latter;

- the need to prove their claims in court since other forms of protection of rights in this respect are absent or ineffective;

- the complexity of collecting relevant evidence base to recourse to court since all transactions with cryptocurrency are carried out electronically.

3. Some rules of the CAO operate with terms, such as "service", "risk", "non-cash forms of payment", which are inherent activities in cryptocurrency relations. An important feature is that these terms apply to accredited business entities, which is not true of electronic services in cryptocurrency market. Positions of administrative liability are complicated by the absence of licenses on such activities by providers of services in cryptocurrency.

4. Criminal liability in cryptocurrency may come for fraudulent actions or legalization (laundering) of proceeds of crime. We can also conclude that the realization of criminal responsibility (correct qualification of criminal offenses) in cryptocurrency relations also depends on licensing activities in Ukraine. If cryptocurrency market actors do not have licenses, any slight sale of Bitcoin to those, who plan to use it in criminal intent, is not sufficient grounds for a charge of the legalization (laundering) of proceeds of crime, even if the criminal intent is apparent in the sale of cryptocurrency. 
Future scientific research in this sphere can include the possibility of arising andimplementation of material liability. Labour relations are developing quickly; in the future, freelance workers could receive wages in cryptocurrency or compensate to the enterprise for damage taking into account the cost of Bitcoin.

Our statements and ideas in no way put the end to cryptocurrency relations study. The issues outlined need further research, while scientific achievements need implementation in the social and legal being.

\section{References:}

Aiganym, E. Seitim. (2016). Analiz kryptovaliuty «bitkoin» na vidpovidnist osnovnym funktsiiam hroshei [Analysis of cryptocurrency «Bitcoin» for concistency with the basic functions of money]. Aktualni problemy ekonomiky [Actual issues of economics], 4 (178), pp. 286-293. (in Ukrainian)

Badzym, O., Drevush, A.. Problemy ta perspektyvy rozvytku elektronnykh valiut [Issues and prospects of electronic currencies development]. Retrieved from http: //www.nbuv.gov.ua/node/2116 (in Ukrainian)

Hava, Yu. V. Kriptovaliuta novoho pokolieniia bitbon [Cryptocurrency of the new generation bitbon]. Investytsiina diialnist [Investment activity]. Retrieved from http: //www.nbuv.gov.ua/node/2116 (in Ukrainian)

Derevianko, B.V. (2017). Ryzyky zdiisnennia operatsii z kryptovaliutoiu (bitkoinamy) hromadian i subiektiv hospodariuvannia Ukrainy [Risks of transactions with cryptocurrency (Bitcoins) by citizens and business entities of Ukraine]. Forum prava [The forum of law], 3, pp. 33-39. (in Ukrainian)

Doronin, I. M. Blokchein, suspilstvo i derzhava: problemy pravotvorchosti. [Blockchain, Society and the State: problems of law-making]. Retrieved from http://aphd.ua/publication-230/ (in Ukrainian)

Neskorodzhena, L. L. (2017). Kryptovaliuta: obiekt tsyvilnykh prav chy zasib platezhu [Cryptocurrency: Object of Civil Rights or Means of Payment]. Suchasna tsyvilistychna nauka v umovakh hibrydnoi viiny [Contemporary civil science in a hybrid war]. Kyiv: Vernadsky Taurida National University, pp. 162-164. (in Ukrainian)

Poplavskyi, O. O. (2016). Kryptovaliuta yak obiekt ekonomichnoho analizu v strakhovykh kompaniiakh [Cryptocurrency as an object of economic analysis in insurance companies]. Journal of ZHDTU, 4 (78), p. 180. (in Ukrainian)

Pantielieieva, N. (2015). Novi formy hroshei v umovakh formuvannia informatsiinoho suspilstva. [New forms of money in the formation of an information society]. Visnyk Natsionalnoho banku Ukrainy [Bulletin of the National Bank of Ukraine], pp. 25-31. (in Ukrainian)

Misnik, N. (2017). Zakonny li bitkoiny v Ukraine [Are the Bitcoins legal in Ukraine?] Retrieved from https://www.epravda.com.ua/rus/publications/2017/08/11/627993/(in Russian)

Kuznetsova, N. S. (2013). Instytut tsyvilno-pravovoi vidpovidalnosti u tsyvilistychnii doktryni Ukrainy [Institute of Civil Liability in the Civil Doctrine of Ukraine]. Doktryna pryvatnoho prava [The Doctrine of Private Law]. In N. S. Kuznetsova, O. Ye. Kharitonov, R. A. Maidanik et al. (Eds). Pravova doktryna Ukrainy: 5 t. [The legal doctrine of Ukraine: in 5 vols], 3 (pp. 330-349). Kh.: Pravo [Law]. (in Ukrainian)

Bodnar, T.V. (2014). Vidpovidalnist za porushennia dohovirnykh zoboviazan [Responsibility for violation of contractual obligations]. In I. Bezklubyi, N. Kuznetsova, R. Maidan et al. (Eds.). Vidpovidalnist u pryvatnomu pravi: monohrafiia [Responsibility in private law: monograph] (pp. 101-117). K.: Diploma. (in Ukrainian)

Bodnar, T.V. (2007). Dohovirni zoboviazannia v tsyvilnomu pravi (zahalni polozhennia): navch. posib. [Contractual obligations in civil law (general terms): tuition manual]. K.: Yustinian [Justinian], 280 p. (in Ukrainian)

Odnostoronnia vidmova $\mathrm{u}$ dohovirnykh zoboviazanniakh [Unilateral refusal in contractual obligations]. In R. A. Maidanyk and O. V. Kokhanovskaya (Eds.). Aktualni problemy pryvatnoho prava: zb. statei do yuvileiu dok. yur. n., prof. N. S. Kuznietsovoi [Actual problems of private law: Articles devoted to the jubilee of Doctor of Science, Prof. N. S. Kuznetsova]. K.: Legal Practice, 2014, pp. 33-50. (in Ukrainian)

Borisova, V.I. (head of authors), Baranova, L. M., Zhilinkova, I. V. et al. (2004). Tsyvilne pravo Ukrainy: pidruchnyk: u 2 t. [Civil law of Ukraine: textbook in 2 vols.]. V. I. Borisova, I. V. Spasibo-Fatieieva, V. L. Yarotskyi (Eds.). K.: Yurinkom Inter, 1, 480 p. (in Ukrainian)

Shevchenko, Ya. M. (2012). Vybrani pratsi [Selected Works] (1964-2012). K.: LLC Printing House «Ruta», 404 p. (in Ukrainian)

Maidanyk, R. A. (2013). Tsyvilno-pravova vidpovidalnist [Civil liability]. In Yu. V. Baulin (Ed.). Yurydychna vidpovidalnist: problemy vykliuchennia ta zvilnennia [Legal liability: issues of exclusion and dismissal]. Donetsk: Kalmius, pp. 86-147. (in Ukrainian)

Biriukov, I. A., Zaika, Yu. A. (Eds.). (2014). Tsyvilne pravo Ukrainy: zahalna chastyna [Civil Law of Ukraine: General Part]. K.: Alerta, 510 p. (in Ukrainian)

Zaika, Yu. O., Timush, I. S., Loviak, O. O. (2014). Ukrainske tsyvilne pravo: navch. posib. 3-tie vyd. pererob. ta dop. [Ukrainian Civil Law: Tuition Manual] (3rd ed.). Yu. O. Zaika (Ed.). K.: Center for Educational Literature, 358 p. (in Ukrainian)

Loviak, O. O. (2014). Normatyvno-pravove zabezpechennia vidshkoduvannia shkody, zavdanoi orhanamy vnutrishnikh sprav Ukrainy: monohrafia [Regulatory and Legal Provision for Compensation for Damage Inflicted by the Internal Affairs Bodies of Ukraine: Monograph]. V. S. Gopanchuk (Ed.). K., 228 p. (in Ukrainian)

Pushkin, A. A, Samoilenko, V. M, Shishka, R. B. et al. (1996). Grazhdanskoie pravo Ukrainy: ucheb. dlia vuzov sistemy MVD Ukrainy [Civil Law of Ukraine: textbook for institutions of higher education of the Ministry of Internal Affairs 
of Ukraine] (Vols. 1-2). A. Pushkin, V. M. Samoilenko (Eds.), 1. Kh.: University of the Internal Affairs; Osnova [Basis], 440 p. (in Russian)

Gribanov, V. P. (1973). Otvietstviennost za narushenie grazhdanskikh prav i obiazannostei [Responsibility for Violation of Civil Rights and Obligations]. M.: Yur. lit. [Law Literature], pp. 16-25. (in Russian)

Uhoda pro vykorystannia servisu PingBlockchain.com. [Agreement on the use of the service PingBlockchain. com.] Retrieved from https://pingblockchain.com/elektronna-valjuta-Bitcoin/ (in Ukrainian)

Tsyvilnyi kodeks Ukrainy [the Civil Code of Ukraine]. (2003). Vidomosti Verkhovnoi Rady Ukrainy [The Official Bulletin of the Verkhovna Rada of Ukraine], 40-44, p. 356. (in Ukrainian)

Loviak, O. O. (2014). Pravovyi pohliad na elektronnyi tsyfrovyi pidpys [Electronic digital signature from a legal perspective]. Suspilstvo ta pravo: naukovyi shliakh [Society and Law: Scientific Path], 1, pp. 5-6. (in Ukrainian)

Rudenko, V., Sadovnichy, V. Status kryptovalyut oholosheno u rozshuk [The status of cryptocurrency is declared to be wanted]. Retrieved from https://finclub.net/ua/analytics/status-kryptovaliut-oholosheno-u-rozshuk.html (in Ukrainian)

Kodeks Ukrainy pro administratyvni pravoporushennia [The Code of Ukraine on Administrative Offenses]. (1984). Vidomosti Verkhovnoi Rady Ukrayinskoi RSR [The Official Bulletin of the Verkhovna Rada of Ukrainian SSR], Annex to No. 51. Art. 1122. (in Ukrainian)

Kodeks Ukrainy pro administratyvni pravoporushennia. Naukovo-praktychnyi komentar [The Code of Ukraine on Administrative Offenses. Scientific and Practical Commentary]. Retrieved from http://mego.info/матеріas/ науково-практичний-коментар-кодексу-україни-про-аАміністративні-правопорушення-пєтков-св-20 (in Ukrainian)

Pro zastosuvannia reiestratoriv rozrakhunkovykh operatsii u sferi torhivli, hromadskoho kharchuvannia ta posluh: Zakon Ukrainy vid 6 lyp. $1995 \mathrm{r}$. [On the application of transactions registrars in trade, catering and services: Law of Ukraine dated July 6, 1995]. Vidomosti Verkhovnoi Rady Ukrainy [The Official Bulletin of the Verkhovna Rada of Ukraine], 28, p. 205. (in Ukrainian)

Kryminalnyi kodeks Ukrainy: Naukovo-praktychnyi komentar [The Criminal Code of Ukraine: Scientific and Practical Commentary]. Retrieved from http://yurist-online.com/ukr/uslugi/yuristam/kodeks/024/ (in Ukrainian)

Shapochka, S. V. (2014). Do pytannia zapobihannia okremym vydam shakhraistva, yake vchyniaietsia z vykorystanniam mozhlyvostei merezhi Internet. [On the issue of preventing certain types of fraud committed using the Internet]. Borotba z orhanizovanoiu zlochynnistiu i koruptsiieiu (teoriia i praktyka) [Fighting Organized Crime and Corruption (Theory and Practice)], 1 (32), p. 145. (in Ukrainian)

Plyta, A. I. Kryptovaliuta: yii pravovyi rezhym, problemy zastosuvannia [Cryptocurrency: its legal organization, problems of application]. Retrieved from http://ukrainepravo.com/legal_publications/essay-on-it-law/it_law_ plyta_\%d1\%81ryptocurrency/ (in Ukrainian) 